\title{
MODEL DISTRIBUSI INDUSTRI PANGAN DI JAWA BARAT DENGAN MENGGUNAKAN PENDEKATAN CAUSAL LOOP SISTEM DINAMIK
}

\author{
Achmad Andriyanto ${ }^{1}$, Amri Yanuar ${ }^{2}$ \\ Prodi D3 Logistik Bisnis, Politeknik Pos Indonesia ${ }^{1}$ \\ email: achmadandriyanto@poltekpos.ac.id ${ }^{1}$ \\ Prodi D4 Logistik Bisnis, Politeknik Pos Indonesia ${ }^{2}$ \\ email: amriyanuar@poltekpos.ac.id ${ }^{2}$
}

\begin{abstract}
Abstrak
Industri pangan menjadi salah satu faktor yang dapat menciptakan stabilitas ekonomi daerah, khususnya di daerah Jawa Barat. Tanaman pangan merupakan salah satu subsektor dari pertanian yang mendominasi di Jawa Barat. Tanaman pangan ini didominasi oleh produksi padi, jagung dan kedelai. Penelitian ini bertujuan untuk membuat model distribusi dari industri pangan yang ada di Jawa Barat. terutama untuk komoditas padi, jagung dan kedelai. Metode yang digunakan untuk menganalisis model distribusinya adalah metode Causal Loop Sistem Dinamik. Dengan Sistem Dinamik diharapkan dapat mengetahui titik lemah proses distribusi yang dilakukan selama ini, sehingga proses distribusinya bisa berjalan dengan baik. Dari model yang dibuat dan dikembangkan dengan metode sistem dinamik, dapat teridentifikasi variabel-variabel apa saja yang berpengaruh terhadap pendistribusian komoditas pangan tersebut. Dari hasil analisis ditemukan bahwa variabel yang mempengaruhi model distribusi komoditas beras di Jawa Barat yaitu: 1) Disparitas harga yang cukup tinggi antara produsen dengan konsumen; 2) Rantai distribusi yang panjang; 3) Kualitas produk; 4) Ketersediaan produk; 5) Tingkat konsumsi masyarakat. Sedangkan variabel yang mempengaruhi model distribusi komoditas jagung pipilan dan kedelai di Jawa Barat yaitu: 1) Kualitas bahan baku; 2) Disparitas harga antar wilayah cukup besar; 3) marjin usaha; 4) Ketersediaan produk; 5) Kualitas produk; 6) Tingkat konsumsi masyarakat.
\end{abstract}

Kata Kunci: Model Distribusi, Industri Pangan, Causal Loop Sistem Dinamik

\begin{abstract}
The food industry is one of the factors that can create regional economic stability, especially in West Java. Food crops are one of the subsectors of agriculture that dominates in West Java. This food crop is dominated by rice, corn and soybean production. This study aims to create a distribution model of the food industry in West Java. especially for rice, corn and soybean. The method used to analyze the distribution model is the Dynamic System Causal Loop method. With the Dynamic System, it is expected to know the weak points of the distribution process carried out so far, so that the distribution process can run well. From the models created and developed by the dynamic system method, it can be identified what variables affect the distribution of these food commodities. From the results of the analysis found that the variables that influence the distribution model of rice commodities in West Java, namely: 1) The price disparity is quite high between producers and consumers; 2) Long distribution chains; 3) Product quality; 4) Product availability; 5) The level of public consumption. While the variables that influence the distribution model of corn and soybean commodities in West Java, namely: 1) The quality of raw materials; 2) Price disparity between regions is quite large; 3) business margin; 4) Product availability; 5) Product quality; 6) The level of public consumption.
\end{abstract}

Keywords: Distribution Models, Food Industry, Causal Loop Dynamic Systems 


\section{PENDAHULUAN}

Jawa Barat merupakan sebuah provinsi yang memiliki jumlah penduduk terbanyak di Indonesia. Menurut data yang diambil dari Badan Pusat Statistik (BPS, 2018), jumlah penduduk Jawa Barat mencapai lebih dari 18 persen dari total penduduk yang ada di Indonesia, yaitu sebanyak 48.683.861 jiwa. Laju pertumbuhan penduduk Jawa Barat sebesar 1,34\%, atau terjadi peningkatan jumlah penduduk sebanyak 0,65 juta jiwa dari tahun 2017. Ketersediaan logistik pangan menjadi hal yang penting dalam kaitannya dengan jumlah penduduk. Pemerintah pusat maupun daerah terus berupaya untuk melakukan usaha-usaha dalam pemenuhan program ketahanan pangan dan ketersediaan logistik pangan. Permasalahan ketersediaan pangan biasanya meliputi produksi, distribusi maupun konsumsi logistik pangan.

Distribusi dari perdagangan merupakan sebuah kegiatan ekonomi yang dilakukan untuk menjembatani antara proses produksi dan konsumsi, sehingga barang dari produsen dapat disalurkan pada konsumen. Distribusi perdagangan terkait erat dengan peran dari setiap mediatornya yang akan berpengaruh terhadap pembangunan perekonomian masyarakat. Jika terjadi efisiensi dari rantai distribusinya, maka pergerakan komoditasnya dapat ditempuh dengan biaya termurah. Hal ini akan berdampak pada pembagian nilai tambahnya, tapi selain itu juga harus memperhatikan masalah yang akan terjadi pada komoditas kebutuhan pokok dari padi seperti beras, dari jagung seperti jagung pipilan dan dari kedelai.

Beras menjadi komoditas yang sangat berperan penting terhadap ketahanan pangan di Indonesia, karena beras merupakan pangan pokok yang utama bagi masyarakat Indonesia itu sendiri. Pangan pokok utama itu dikonsumsi oleh sebagian besar dari penduduk yang ada (Khumaidi, 1997) dan dalam situasi dan kondisi yang normal tidak tergantikan oleh komoditas yang lain (Hessie, 2009). Jika melihat hal tersebut, maka aspek dari proses penyediaan serta pendistribusian dari komoditas beras ini menjadi hal yang sangat penting karena sangat besarnya jumlah penduduk Indonesia dan pertambahan jumlah penduduknya.

Jagung pipilan menjadi salah satu komoditas dari palawija yang memiliki peranan sangat penting karena memiliki sumber protein dan kalori yang sangat dibutuhkan. Jika dibandingkan dari nilai nutrisinya, jagung pipilan memiliki nilai nutrisi yang hampir seimbang dengan nilai nutrisi yang dimiliki oleh beras. Bahkan jagung pipilan juga memiliki peranan sebagai sumber bahan makanan pokok dapat menggantikan beras.

Kedelai menjadi bahan pokok dari pangan yang memiliki peranan sangat penting karena dapat menyediakan protein asam amino esensial yang dibutuhkan agar tercapai gizi pangan yang seimbang. Dalam proses permintaannya, permintaan dari kedelai terbilang sangat tinggi baik dalam hal konsumsi langsung atau produk olahan dari kedelai. Hal ini dapat menyebabkan kelangkaan pasokan kedelai dan meningkatnya harga kedelai di Indonesia. Jika dilihat dari sumber daya alamnya yang lebih, Indonesia masih melakukan proses impor kedelai dari negara lain untuk memenuhi permintaannya.

Penelitian ini memiliki tujuan untuk membuat model distribusi dari industri pangan baik untuk komoditas padi, jagung maupun kedelai di Jawa Barat. Metode yang digunakan untuk menganalisis model distribusinya adalah metode Causal Loop Sistem Dinamik. Dengan Sistem Dinamik diharapkan dapat mengetahui titik lemah proses distribusi yang dilakukan selama ini, sehingga proses distribusinya bisa berjalan dengan baik. Dari model yang dibuat dan dikembangkan dengan metode sistem dinamik, dapat teridentifikasi variabel-variabel apa saja yang berpengaruh terhadap pendistribusian komoditas pangan tersebut. 


\section{METODE PENELITIAN}

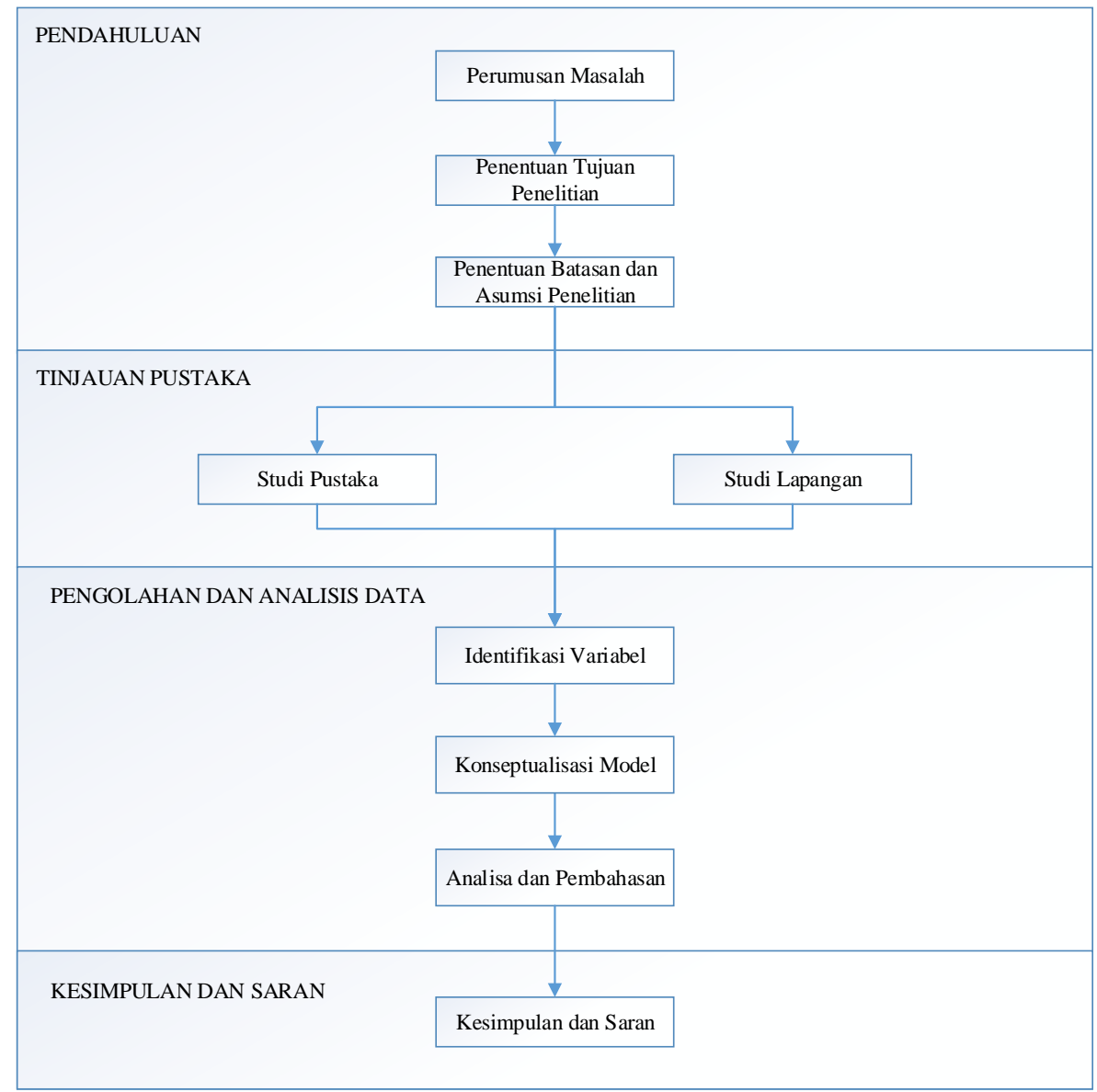

Gambar 1. Metodologi Penelitian

\subsection{Identifikasi Variabel}

Dengan dilakukan proses pendefinisian sistem pada proses distribusinya, maka akan dapat mengidentifikasi variabel atau elemen-elemen yang saling berinteraksi dan saling berpengaruh di dalam proses pendistribusiannya serta akan mengetahui juga batasan-batasan yang ada dalam sistem pendistribusian ini. Identifikasi variabelnya didapatkan dengan dari karakteristik dan perilaku yang mempengaruhi proses distribusinya. Setelah didapatkan variabel-variabelnya, kemudian variabel tersebut di modelkan dan disimulasikan.

\subsection{Konseptualisasi Model}

Untuk mempermudah dalam melihat hubungan antar variabel atau elemen yang telah didapatkan dari pendefinisian sistem distribusinya, dibuatlah model kausatik dalam bentuk Causal Loop Diagram (CLD). CLD yang dibuat akan menggambarkan kejadian-kejadian berupa hubungan sebab akibat (Causal Relationship) dari variabel-variabel yang terbentuk.

\section{HASIL DAN PEMBAHASAN}

\subsection{Identifikasi Variabel}

Dari identifikasi awal, beberapa faktor yang mempengarui pola distribusi beras adalah:

a. Disparitas harga yang cukup tinggi antara produsen dengan konsumen; 
b. Rantai distribusi yang panjang;

Beberapa faktor yang mempengarui pola distribusi jagung pipilan adalah:
a. Kualitas bahan baku;
b. Disparitas harga antar wilayah cukup besar;
c. Marjin usaha;

Beberapa faktor yang mempengarui pola distribusi kedelai adalah:
a. Kualitas bahan baku;
b. Disparitas harga antar wilayah cukup besar,
c. Marjin usaha;

\subsection{Konseptualisasi Model}

Dalam pembuatan model dari penyediaan padi dibangun berdasarkan submodel penggunaan lahan, konsumsi dan produksi (Nugraha, 2018). Sedangkan untuk pembuatan model persediaan beras dibangun berdasarkan subsistem populasi, penggunaan lahan dan produksi beras (Budiawan, Arvianto, $\&$ Hadi, 2017). Terkait dengan produksi beras tersebut terdapat dua variabel penting yang berpengaruh terhadap sistem produksi secara keseluruhan, yaitu variabel produktivitas dan ketersediaan lahan (Wibowo, 2016). Dari hal tersebut akan mempengaruhi terhadap ketersediaan beras, sebagai contoh pada tahun 2014 ketersediaan beras di Jawa Timur telah menargetken $60 \%$ dari surplus 10 juta ton beras nasional belum bisa tercapai (Garside \& Asjari, 2015).

Model neraca jagung di Jawa Barat mendekati pada kondisi nyata, hal ini dipengaruhi oleh peningkatan produksi melalui peningkatan produktivitas dengan substitusi benih jagung komposit menjadi benih jagung hibrida dan dilakukan penanaman dengan benih jagung hibrida dan penggunaan teknologi mesin pengering (dryer) (Rachmawati, 2016).

Produksi kedelai dapat diproduksi untuk memenuhi kebutuhan permintaan kedelai di Indonesia selama 20 tahun dengan meningkatkan ekspansi lahan minimal $70 \%$ per tahun, penggunaan benih dengan tingkat produksi minimum 2,4 ton / hektar atau pemanfaatan benih berumur pendek yang mampu meningkatkan indeks tanam minimal 2.0, penggunaan pupuk hayati yang dapat meningkatkan produktivitas benih minimal 125\% (Hasan, Suryani, \& Hendrawan, 2015). Sedangkan untuk faktorfaktor yang mempengaruhi ketersediaan kedelai terutama di Provinsi Bali yaitu:
a. Luas areal tanam,
b. Luas panen,
c. Produksi kedelai,
d. Perdagangan antarpulau,
e. Persentase lahan yang dipanen,
f. Produktivitas lahan,
g. Teknologi intensifikasi,
h. Laju ekstensifikasi,
i. Laju konversi lahan,
j. Pertumbuhan penduduk,
k. Net migrasi,
1. Kebutuhan industri tempe dan tahu,
m. Kebutuhan industri susu kedelai,
n. Kebutuhan industri makanan ringan kedelai (Krisdayanti, Satriawan, \& Yoga, 2017). 
a. Pola Distribusi

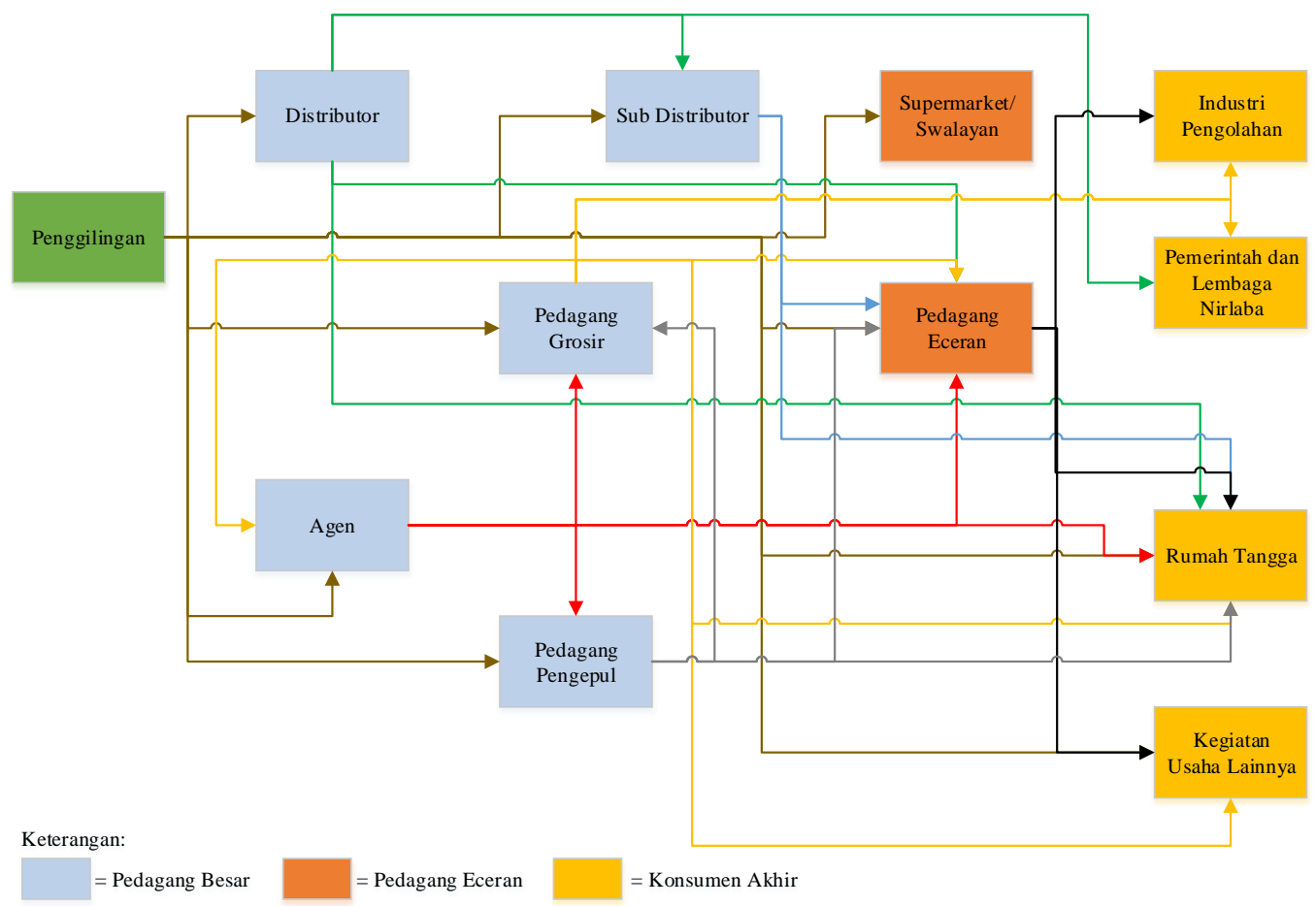

Gambar 2. Pola Distribusi Perdagangan Beras di Provinsi Jawa Barat Sumber: Badan Pusat Statistik (BPS)

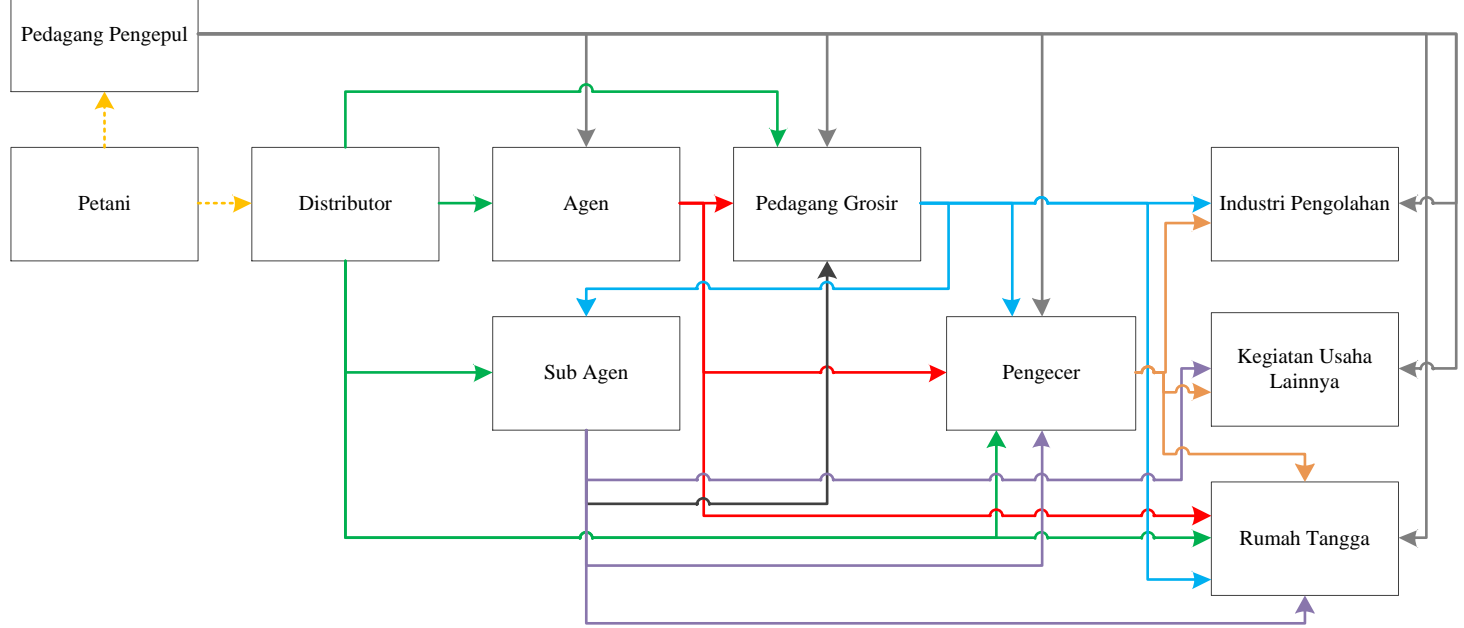

Gambar 3. Pola Distribusi Perdagangan Jagung Pipilan di Provinsi Jawa Barat Sumber: Badan Pusat Statistik (BPS) 


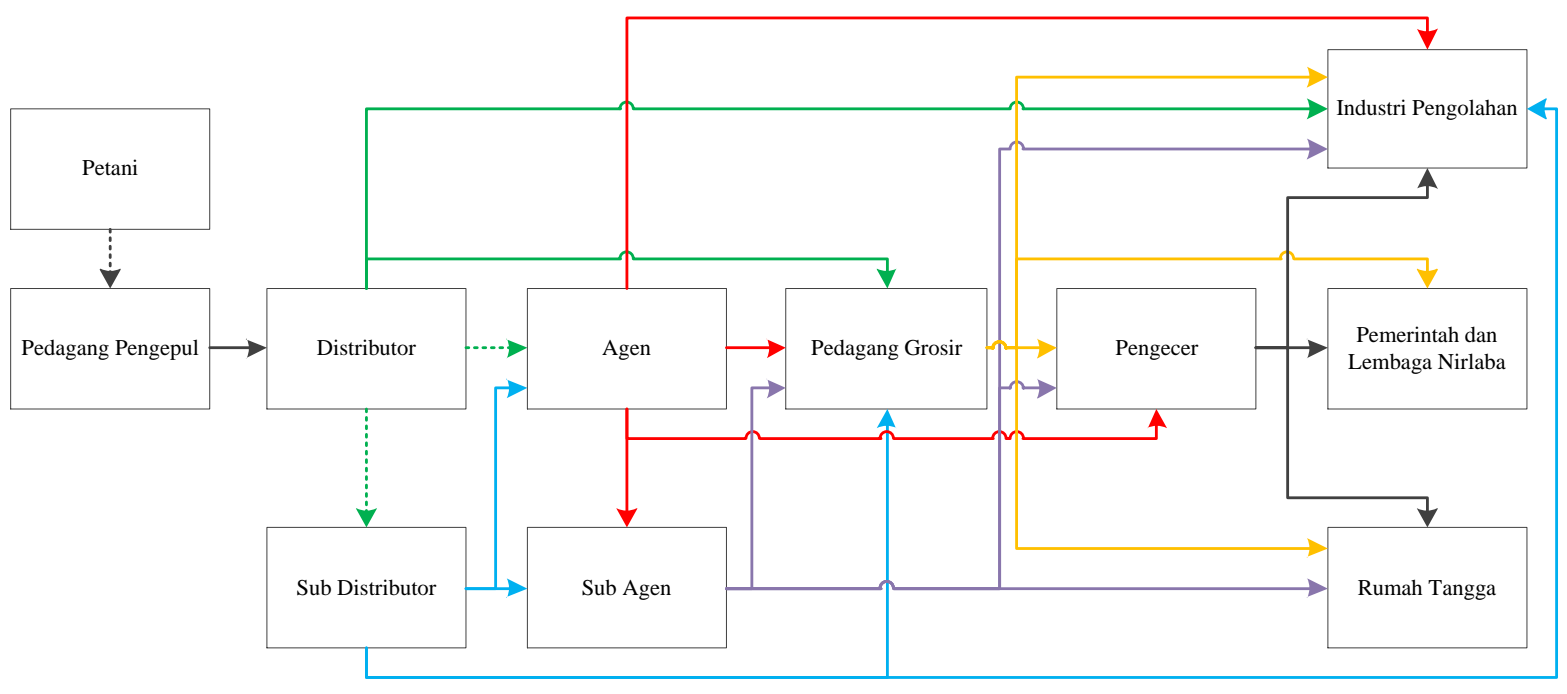

Gambar 4. Pola Distribusi Perdagangan Kedelai di Provinsi Jawa Barat Sumber: Badan Pusat Statistik (BPS)

b. Causal Loop Diagram

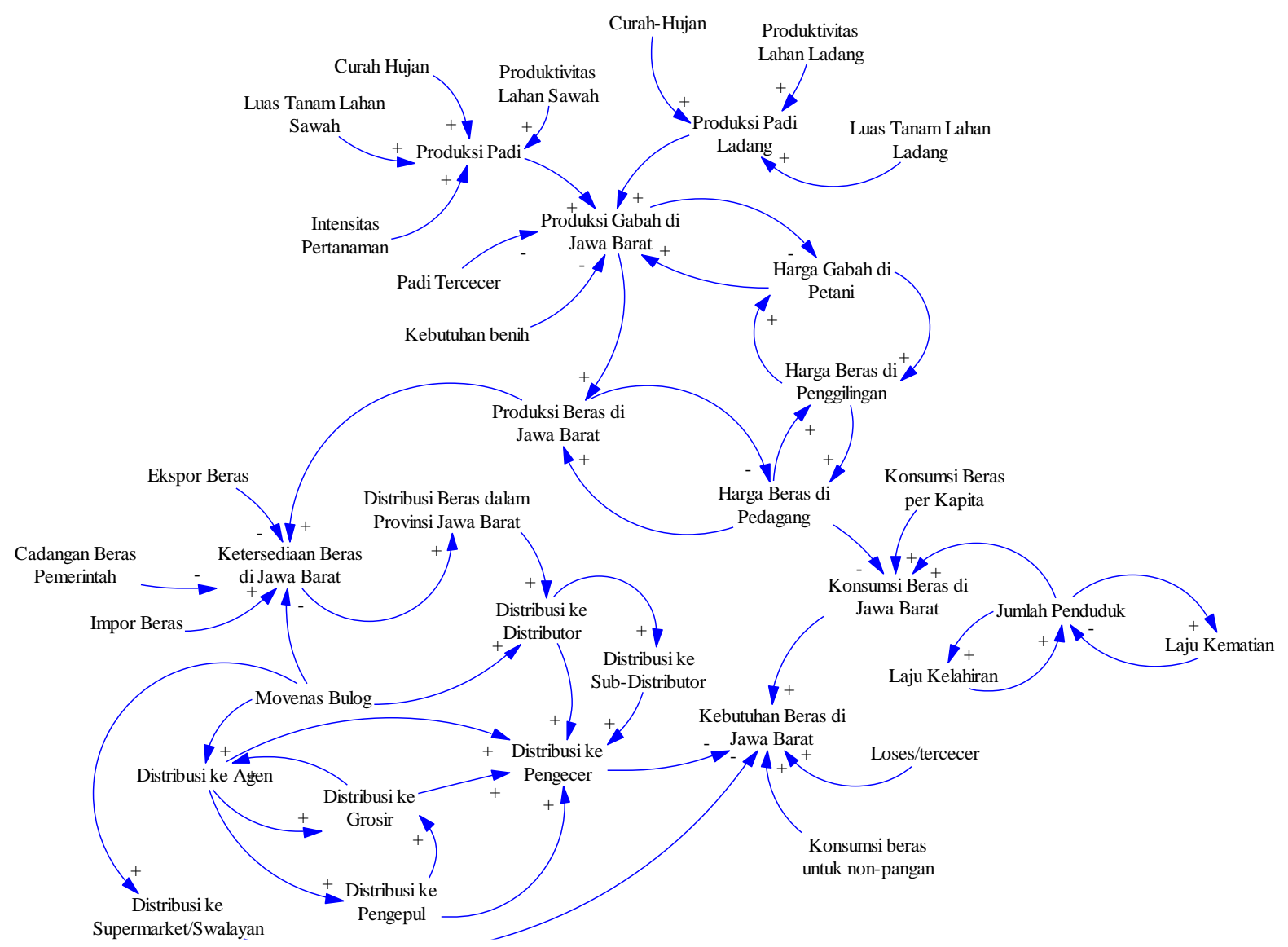

Gambar 5. Causal Loop Diagram Rantai Pasok dan Distribusi Beras Jawa Barat 


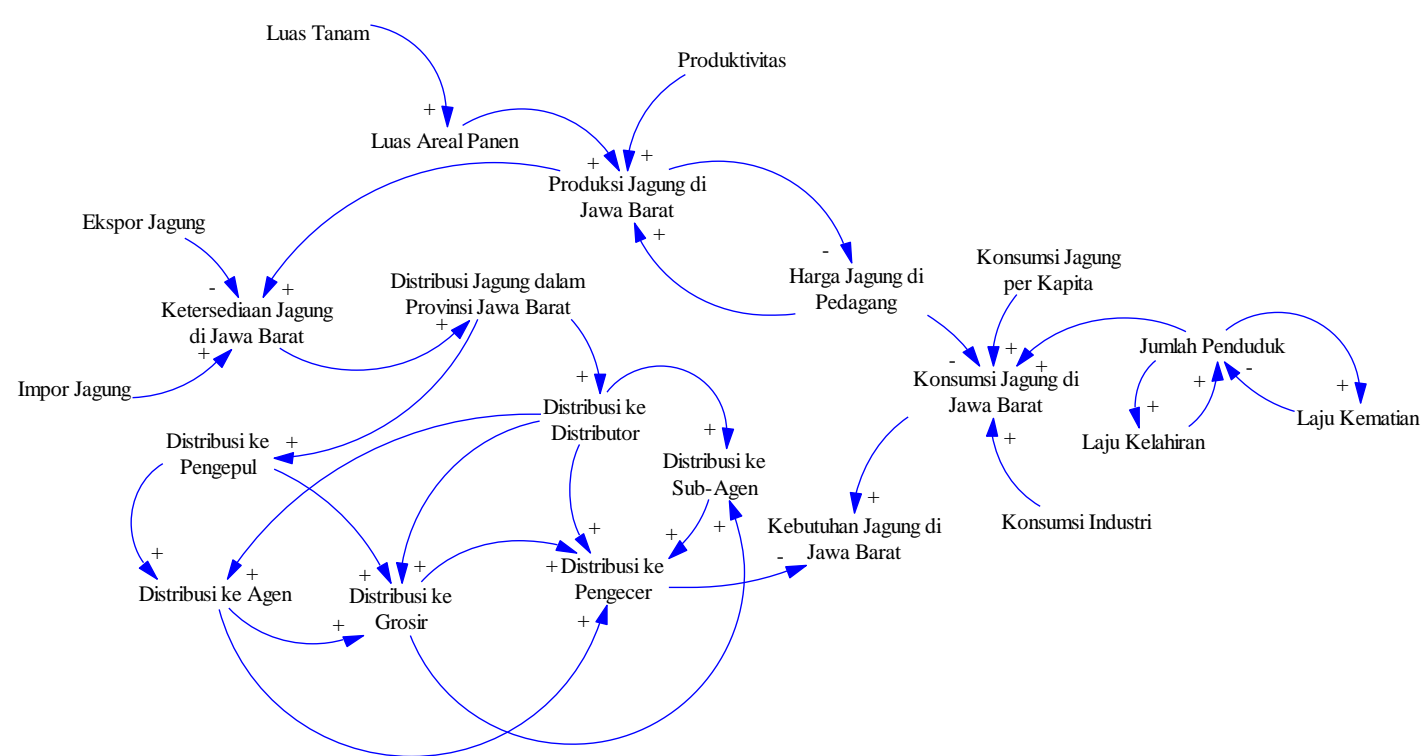

Gambar 6. Causal Loop Diagram Rantai Pasok dan Distribusi Jagung Pipilan Jawa Barat

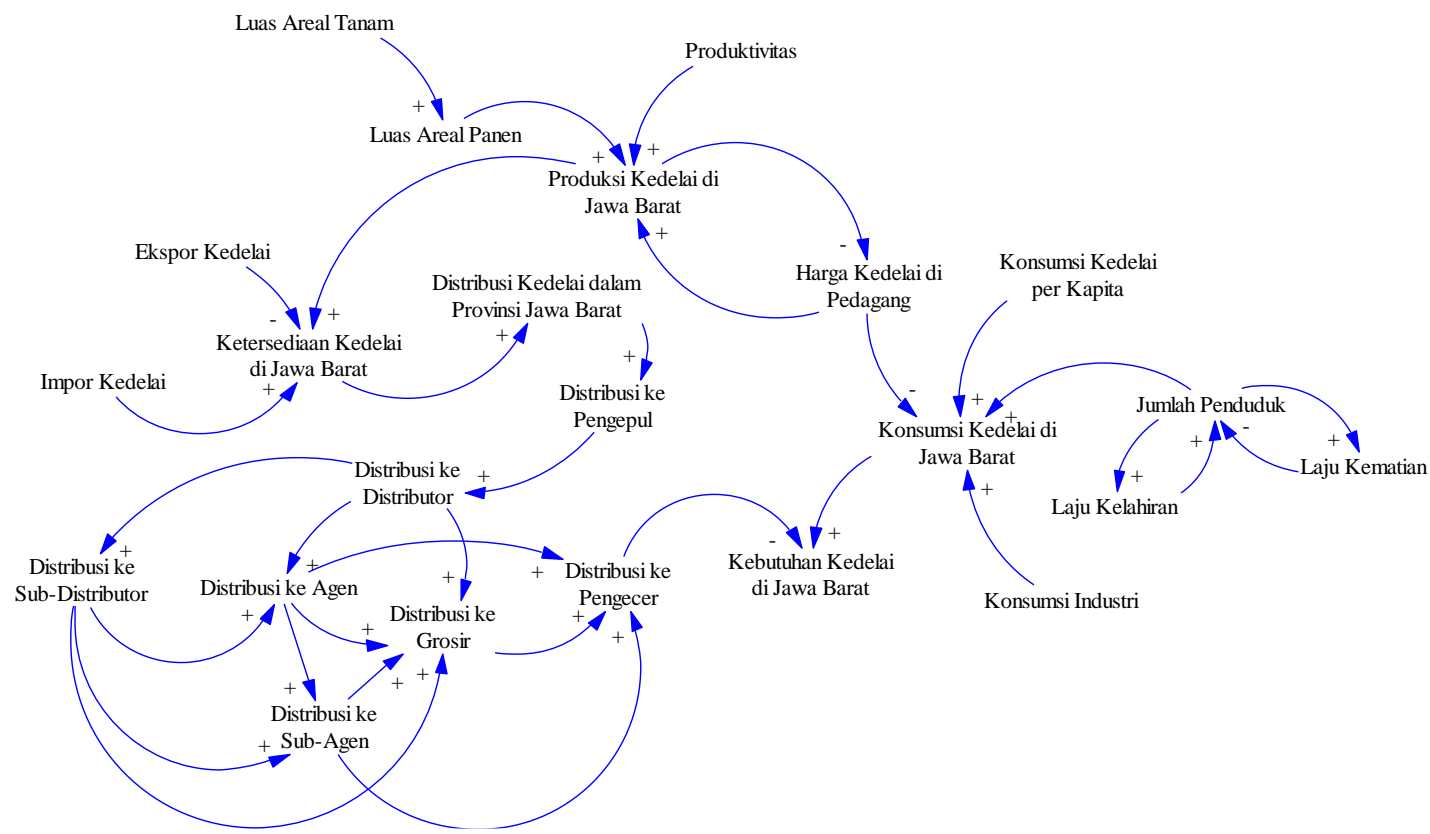

Gambar 7. Causal Loop Diagram Rantai Pasok dan Distribusi Kedelai Jawa Barat

Baik dari pola distribusi maupun dari causal loop diagramnya, industri pangan memiliki rantai distribusi yang panjang sehingga menyebabkan tingkat kompleksitas yang tinggi dari proses distribusinya. Oleh karena itu, perlu dilakukan efisiensi proses dari rantai distribusinya sehingga proses distribusi yang terjadi bisa berjalan dengan baik dan lebih efisien.

Secara umum berdasarkan model causal loop yang dibuat, variabel yang mempengaruhi model distribusi komoditas beras di Jawa Barat yaitu: 1) Disparitas harga yang cukup tinggi antara produsen dengan konsumen; 2) Rantai distribusi yang panjang; 3) Kualitas produk; 4) Ketersediaan produk; 5) Tingkat konsumsi masyarakat. Variabel yang mempengaruhi model distribusi komoditas jagung pipilan di Jawa Barat yaitu: 1) Kualitas bahan baku; 2) Disparitas harga antar wilayah cukup besar; 3) marjin usaha; 4) Ketersediaan produk; 5) Kualitas produk; 6) Tingkat konsumsi masyarakat. Variabel yang mempengaruhi model distribusi komoditas kedelai di Jawa Barat yaitu: 1) Kualitas bahan baku; 2) Disparitas harga antar wilayah cukup besar; 3) marjin usaha; 4) Ketersediaan produk; 5) Kualitas produk; 6) Tingkat konsumsi masyarakat. 
Untuk memastikan variabel-variabelnya mempengaruhi model distribusinya dilakukan proses verifikasi menggunakan Vensim dan dilakukan proses validasi dengan menghitung mean comparison $<5 \%$ dan memiliki error variance $<30 \%$, sehingga didapatkan model yang dapat merepresentasikan dengan kondisi saat ini.

\section{KESIMPULAN DAN SARAN}

Dari hasil analisis dan pembahasan yang dilakukan, secara umum variabel yang mempengaruhi model distribusi komoditas industri pangan di Jawa Barat yaitu: 1) Disparitas harga yang cukup tinggi; 2) Rantai distribusi yang panjang; 3) Kualitas produk; 4) Ketersediaan produk; 5) Tingkat konsumsi masyarakat; 6) Kualitas bahan baku; 7) Marjin usaha. Dari beberapa variabel yang mempengaruhinya tersebut, jika dilihat dari pola distribusi dan causal loop diagramnya industri pangan memiliki variabel yang sangat mempengaruhinya yaitu rantai distribusi yang panjang sehingga menyebabkan tingkat kompleksitas yang tinggi dari proses distribusinya. Oleh karena itu, perlu dilakukan efisiensi proses dari rantai distribusinya sehingga proses distribusi yang terjadi bisa berjalan dengan baik dan lebih efisien.

\section{REFERENSI}

BPS. (2018). Diambil kembali dari https://jabar.bps.go.id/

Budiawan, W., Arvianto, A., \& Hadi, M. N. (2017). Analisis Kebijakan Persediaan Beras Provinsi Jawa Tengah Menggunakan Pendekatan Sistem Dinamik. Seminar dan Konferensi Nasional IDEC, (hal. 292-302). Surakarta.

Garside, A. K., \& Asjari, H. y. (2015). Simulasi Ketersediaan Beras di Jawa Timur. Jurnal Ilmiah Teknik Industri (JITI), 14(1), 47-58.

Hasan, N., Suryani, E., \& Hendrawan, R. (2015). Analysis of Soybean Production And Demand to Develop Strategic Policy of Food Self Sufficiency: A System Dynamics Framework. Procedia Computer Science, 72, 605-612.

Hessie, R. (2009). Analisis Produksi Dan Konsumsi Beras Dalam Negeri Serta Implikasinya Terhadap Swasembada Beras Di Indonesia. Bogor: IPB.

Khumaidi, M. (1997). Beras Sebagai Pangan Pokok Utama Bangsa Indonesia, Keunikan dan Tantangannya. IPB. Bogor.

Krisdayanti, N. L., Satriawan, I., \& Yoga, I. S. (2017). Sistem Dinamik Ketersediaan Kedelai Dalam Rangka Swasembada Pangan Di Provinsi Bali. Jurnal Rekayasa dan Manajemen AgroIndustri, $5(3), 45-56$.

Nugraha, A. A. (2018). Model Penyediaan Pangan Padi di Kabupaten Bandung Barat. Bogor: IPB.

Rachmawati, L. F. (2016). Rekayasa Model Sistem Dinamik Komoditas Jagung Untuk Mendukung Program Upaya Khusus di Jawa Barat. Bogor: IPB.

Wibowo, A. D. (2016). Dinamika Ketersediaan Beras : Sebuah Studi Kasus di Kalimantan Selatan. Jurnal Ziraa'ah, 41(2), 242-249. 